\title{
KATA ACIL “BIBI” DALAM BAHASA BANJAR BERDASARKAN KATEGORI SAPAAN
}

\section{THE USE OF WORD ACIL "AUNTIE" IN BANJARESE LANGUAGE BASED ON CONVIVAL CATEGORY}

\author{
Rissari Yayuk \\ Balai Bahasa Kalimantan Selatan \\ Jalan A. Yani. KM 32,2. Lok Tabat. Banjarbaru. \\ Kalimantan Selatan \\ Pos-el: yrissariyayuk@yahoo.co.id, Telepon: 089691827674
}

\begin{abstract}
A bstract
Theuse of getings in a speech commuity required thenules of their use Ladks of undestanding of theprdbemwill makea pesson vidatethenules of politeness in languagealturethat preail in a language commmity. Theprdbem

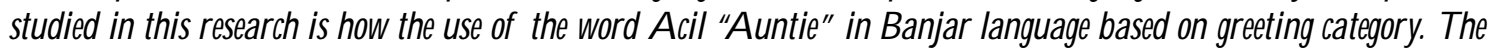
purposeof thisstudyistodescribetheuseof thewordA dil "A untie" inBanjarlangragebasel on thegretingcategry. Thetype of thisrearchis descriptivequalitative Data clletion wastakenin Gambahvillage, Hulu Sungai Sdatan Reegny, Sath Kalimantan Proince Data colletion was hdd on January2017 toJune2017. It vas donebyusing dbservation mothod with tappingandinvdved convesation technique Thedata analysis was doneby companing The deteminant of this method is a non-langrage dement. His m thod of detemining thetod is autside thelangrage or pragnatic, so that the deteminant is the qposite Therencher tok threesteps of work. They are colletion, data proessing andanalysispresentation. Theresult of thisrearchis theuseof gretingAd "Auntie" in Banjarpeeple based ongeting cateegry consisting of affection cateegry, kinship, honorificgreting nidkname, and "calling" cateegry.
\end{abstract}

Keywords: Adil, Banjar, geeting

\begin{abstract}
Abstrak
K ata sapaan dalam sebuah komunitas tutur penting diketahui penggunaannya. Ketidakpahaman akan masalah tersebut akan membuat seseorang menyalahi aturan budaya santun berbahasa yang berlaku pada komunitas bahasa tersebut. Masalah yang dikaji dalam penelitian ini, yaitu bagaimana penggunaan kata Acil "Bibi" dalam bahasa Banjar berdasarkan kategori sapaan. Tujuan penelitian adalah mendeskripsikan penggunaan kata Acil "Bibi" dalam bahasa Banjar berdasarkan kategori sapaan. Jenis penelitian ini adalah deskriptif kualitatif. Pengumpulan data dilakukan di desa $\mathrm{G}$ ambah, Kabupaten Hulu Sungai Selatan, Provinsi K alimantan Selatan. Waktu pengumpulan data selama bulan JanuariJuni 2017. Pengumpulan data dilakukan dengan metode simak dengan teknik sadap dan teknik libat langsung. Pengkajian data melalui metode padan. Metode ini alat penentunya adalah di luar bahasa atau pragmatik sehingga yang menjadi penentu adalah lawan bicaranya. Penulis menempuh tiga langkah kerja, yaitu tahap pengumpulan data, pengolahan data, dan penyajian hasil analisis data. Hasil penelitian yang diperoleh, yaitu penggunaan kata sapaan Acil "Bibi" dalam masyarakat Banjar berdasarkan kategori sapaan terdiri atas kategori panggilan sayang, hubungan kekerabatan, sapaan hormat, panggilan julukan, dan kategori "memanggilkan".
\end{abstract}

Kata kunci: Acil, Banjar, sapaan 


\section{PENDAHULUAN}

Bahasa dianalogikan sebagai sebuah alat dengan kaidah-kaidah yang sangat rumit dan dipergunakan untuk mengatur bagaimana seseorang bertutur agar hubungan interpersonalnya senantiasa terpelihara Wijana, dkk., (2011:1). Pendapat ini menekankan bahwa penggunaan bahasa oleh seseorang harus memperhatikan kaidah penggunaan bahasa agar hubungan sosial antarpenutur dapat terjalin dengan baik. Salah satu wujud penggunaan bahasa yang dapat menjalin hubungan sosial, yaitu melalui sapaan yang menunjukkan keramahtamahan dan kesantunan para penutur bahasa yang berbeda-beda tergantung kepada sosial budaya masyarakat penutur bahasa tersebut. KBBI (2008:1225) menyatakan bahwa sapaan adalah kata atau frasa yang digunakan untuk menegur berdasarkan hubungan dengan lawan bicara.

Crystal dalam Chaer, 2012:10) menyatakan bahwa sistem sapaan pada bahasa tertentu berbeda pada bahasa lain yang pembedanya terletak pada aspek sosiokultural pada setiap masyarakat penggunanya.

Masyarakat Banjar mengenal salah satu sapaan yang digunakan dengan tujuan sosial, yaitu panggilan untuk menegur seseorang dengan sebutan Adil "Bibi". Sapaan ini digunakan tidak untuk mitra tutur yang memiliki hubungan kekerabatan dengan penutur saja, tetapi faktor lain juga ikut terlibat. Ketidakpahaman atas penggunaan kata sapaan dalam masyarakat Banjar ini akan menyebabkan pelanggaran budaya santun dalam berbahasa. Sebaliknya, jika partisipan menggunakan kata Adil "Bibi" ini sesuai dengan konteks sosial budaya pada masyarakat Banjar maka dianggap telah melakukan tindak kesantunan.

Sementara itu, dalam kehidupan komunikasi sehari-hari, pengguna bahasa Banjar ini secara umum, tidak hanya berasal dari suku Banjar, tetapi juga berasal dari suku pendatang, seperti Jawa, Madura, Bali, dan lain-lain. Hal ini tidak mengherankan sebab bahasa Banjar merupakan bahasa perhubungan antarsuku di Kalimantan Selatan. Oleh sebab itu, bagi merekayang berasal dari ragam suku di Kalimantan Selatan yang memilih bahasa Banjar sebagai bahasa perhubungan saat berkomunikasi, alangkah tepat jika mengetahui dan menguasai aspek-aspek kebahasaan yang berkaitan dengan bahasa Banjar, salah satunya tentang sistem sapaan.

Penelitian ini mengemukakan wujud sapaan yang berkaitan dengan judul. Pengetahuan ini sangat bermanfaat untuk mendokumentasikan sebuah budaya tutur yang menggunakan sapaan ramah atau santun. Sapaan ramah dan santun yang ditujukan kepada seseorang saat ini sudah mengalami pergeseran. Kajian tentang sapaan dalam bahasa Banjar secara umum masih sedikit. D unia pendidikan di Kalimantan Selatan masih memerlukan ragam kajian tentang sapaan bahasa Banjar, sebagai salah satu pendukung materi ajar yang selama ini sukar mereka dapatkan. Berdasarkan paparan di atas, penulis merasa penting untuk meneliti penggunaan kata sapaan Adi "Bibi" dalam masyarakat Banjar. Masalah yang diangkat, yaitu bagaimana penggunaan kata Adi "Bibi" dalam bahasa Banjar berdasarkan kategori sapaan. Tujuan penelitian ini mendeskripsikan penggunaan kata Adil "Bibi" dalam bahasa Banjar berdasarkan kategori sapaan.

Upaya ini hanya kerja kecil yang dilakukan penulis untuk menambah khazanah pustaka bahasa daerah yang dapat dimanfaatkan. Penelitian tentang kata sapaan dalam bahasa Banjar telah dilakukan oleh Nengsih (2013) dengan judul "Variasi Panggilan dalam Tuturan Sapaan Masyarakat Banjar". Nengsih hanya menyebutkan variasi sapaan bagi masyarakat Banjar berdasarkan kajian sosiolinguistik. Sementara itu, penelitian 
tentang variasi sapaan untuk bahasa daerah lain pernah dilakukan oleh Geza (2016) dengan judul "Variasi Kata Sapaan Kdkerabatan Bahasa Mdayu Jambi di Desa Bukit Telago". G eza mengkaji penggunaan variasi sapaan kekerabatan penutur bahasa Melayu Jambi di Desa Bukit Telago.

Berdasarkan dua penelitian tersebut, penelitian yang khusus memaparkan penggunaan kata Acil "Bibi" pada masyarakat Banjar berdasarkan kategori sapaan berdasarkan kajian sosiopragmatik belum dilakukan. Tarigan (2009:15) menyatakan bahwa sosiopragmatik adalah telaah mengenai kondisi setempat atau lokal mengenai penggunaan bahasa yang dipengaruhi oleh kondisi tempat bahasa itu digunakan. Pembahasan tentang sosiopragmatik dibahas juga oleh Rahardi (2009:5). Dia menyatakan bahwa sosiopragmatik adalah telaah bahasa yang berfokus kepada keberadaan budaya setempat atau kultur. Termasuk di dalamnya mencakup masalah kesantunan berbahasa.

\section{KAJIAN TEORI}

\subsection{Sapaan}

Variasi pemakaian bahasa mencerminkan pemakaian bahasa atau masyarakat penuturnya. Variasi bahasa dalam sapaan dapat dipengaruhi oleh tempat, waktu, dan hubungan partisipan. Setiap variasi bentuk sapaan yang dipilih mengandung nilai simbolis tertentu. Nilai yang dilambangkan dengan penggunaan bentuk-bentuk kebahasaan termasuk pula bentuk sapaan, antara lain sikap dan perasaan hormat terhadap pihak yang disapa (Fisman dalam Nengsih, 2013:50).

Chaer (2010:104-105) menyatakan sapaan adalah ujaran santun yang digunakan untuk menegur atau memanggil mitra tutur dalam situasi tertentu. Ujaran ini bisa berupa kata, frasa, kalimat, bahkan narasi. Sapaan ini biasanya disertai dengan unsur kinetik pendukung keramahtamahan, seperti senyum dan anggukan kepala. Sapaan yang dilakukan penutur dan mitra tutur ini akan menciptakan situasi yang harmonis dan menyenangkan. Misalnya, penutur melewati mitra tutur yang sedang duduk, alangkah baiknya memanggil namanya seraya berujar pemis. Hal ini menunjukkan bahwa penutur menghargai dan menghormati mitra tutur. Penutur bertegur sapa sambil meminta izin.

Nengsih (2013:46) menyatakan bahwa dalam menjaga kelangsungan komunikasi yang baik, masyarakat Banjar saling bertegur sapa dengan menggunakan kata ganti nama yang santun disesuaikan dengan situasi dan kondisi. Panggilan untuk menyapa orang lain atau orang kedua bertujuan untuk menarik perhatian, menjalin percakapan, serta menjalin hubungan sosial.

Jahdiah ( 2003: 61-63) menyatakan sapaan secara umum dalam masyarakat Banjar bermacam-macam penggunaannya, seperti dalam keluarga, masyarakat, resmi, tamu, dan keagamaan. Biber (dalam Isa 2010:46) menekankan bahwa sapaan penting untuk menjelaskan dan memelihara hubungan sosial antara partisipan di dalam percakapan. Mereka membagi sapaan menjadi delapan kategori berdasarkan penggunaannya, yaitu (1) panggilan sayang; (2) istilah kekerabatan; (3) panggilan akrab; (4) nama akrab; (5) nama depan utuh; (6) gelar dan nama belakang; (7) sapaan hormat; dan (8) sapaan lain yang termasuk julukan.

Nengsih (2013:53 - 77) menyatakan bahwa panggilan sayang digunakan saat menyapa lawan bicara yang mempunyai sifat hubungan intim, akrab, dan penuh kasih. Panggilan kekerabatan merupakan suatu bentuk hubungan keturunan dan perkawinan. Akrab adalah modifikasi dari nama seseorang dengan pengubahan bentuk yang tidak beraturan. Julukan adalah nama secara tidak resmi untuk memanggil seseorang berdasarkan nama diri, sifat, pekerjaan, atau ciri khas fisik pemilik nama. 
Sapaan hormat berkaitan dengan tujuan kesantunan. Sapaan ini dilakukan karena adanya perasaan ingin menghargai, menghormati, dan perasaan takzim terhadap seseorang. Tim (2008:507) menyatakan bahwa hormat adalah perbuatan menghargai, sopan, atau menyatakan perasaan takzim.

Sapaan untuk nama depan utuh berkaitan dengan panggilan nama seseorang yang nama depannya tidak dipenggal atau dikurangi.

\subsection{Bentuk Tindak Tutur}

Rahardi (2009:17) menyebutkan, berdasarkan Searle (1975) ada lima bentuk tindak tutur yang dilakukan orang sewaktu memproduksi ujaran dilihat dari fungsi ilokusinya. Lima tindak tutur ini meliputi representatif atau asertif, direktif, ekspresif, komisif, dan deklarasi. Tindak tutur representatifberkaitan dengan pernyataan melaporkan dan menyebutkan. Dirkktif berkaitan dengan tindak tutur agar mitra tutur melakukan tindakan yang diinginkan penutur, seperti perintah dan menantang. Ekspresifberkaitan dengan pujian dan ucapan terima kasih. Komisif berkaitan dengan ancaman. Deklarasi berkaitan dengan keputusan.

\subsection{Modus Tuturan}

Modus tuturan terbagi menjadi tiga, yakni tuturan bermodus deklaratif, modus interogatif, dan modus imperatif (Wijana, dkk, 2011:193197). Berdasarkan pendapat ini, hal ini berarti ketiga modus memiliki penjelasan dan ciri-ciri sebagai berikut (1) Modus ddklaratif digunakan untuk memberitakan sesuatu (informasi). Secara konvensional modus deklaratif ditandai dengan tanda titik dan diucapkan dengan intonasi yang datar. (2) Modus interogatif digunakan untuk menanyakan sesuatu. Secara konvensional modus interogatif ditandai dengan tanda tanya dan disertai dengan intonasi yang sedikit naik. (3) Modus Imperatif digunakan untuk menanyakan perintah, ajakan, dan permintaan atau permohonan. Secara konvensional, modus imperatif ditandai dengan tanda seru dan diucapkan dengan intonasi naik. Ciri-ciri modus tuturan adalah (1) kata, (2) intonasi (tanda baca), dan (3) konteks.

\subsection{Tujuan Tindak Tutur}

Tindak tutur berdasarkan tujuan terdiri atas tindak tutur konfliktif, kompetitif, kolaboratif, dan konvival (Leec dalam Baryadi, 2012:31-32). Berdasarkan pendapat ini, konfliktif adalah adalah tindak tutur yang berlawanan dengan tujuan sosial, seperti membentak, mengusir, dan lain-lain. Kompetitif adalah tindak tutur yang bersaing dengan tujuan sosial, seperti memerintah, menilai, dan lain-lain. Kdaboratif adalah tindak tutur yang tidak menghiraukan tujuan sosial, seperti mengumumkan. Konvival adalah tindak tutur yang sejalan dengan tujuan sosial, seperti mengundang, melucu, bercanda, dan lain-lain.

\subsection{Peristiwa Tutur}

Hymes dalam Aslida, dkk., (2010:31-32) mengemukakan bahwa suatu peristiwa tutur harus memenuhi delapan komponen yang tersimpulkan dalam akronim SPEAKING. Kedelapan komponen tersebut adalah:

S : Setting berhubungan dengan waktu, tempat berbicara dan suasana bicara. Settingyang berbeda menyebabkan penggunaan bahasa berbeda. Penggunaan bahasa di tengah lapangan bola yang ramai akan berbeda ketika menggunakan bahasa di perpustakaan yang sepi.

P : Partiapant, adalah pihak-pihak yang terlibat dalam pertuturan

E : End merupakan maksud dan tujuan pertuturan A : Ad Sequees adalah bentuk ujaran atau suatu peristiwa seorang pembicara sedang mempergunakan kata-kata yang berisi pembicaraan.

$\mathbf{K}$ : Key, mengacu pada nada suara, cara dan ragam bahasa yang digunakan dalam menyampaikan 
pendapatnya, dan cara mengemukakan pendapatnya, seperti sedih, gembira, dan serius.

I : Instrumet, mengacu pada jalur bahasa yang digunakan seperti bahasa lisan, bahasa tulis, dan mengacu pada kode ujaran yang digunakan, seperti oral, isyarat, tulisan, telegraf, dialek, dan lainlain

$\mathbf{N}$ : Nom, yaitu aturan dalam berinteraksi misalnya, yang berhubungan dengan aturan atau kesantunan memberi tahu, memerintah, bertanya, minta maaf, basa-basi, mengkritik, dan sejenisnya. Hal ini berkaitan dengan hubungan sosial dalam sebuah masyarakat tutur.

G : Genre, yaitu bentuk penyampaian, seperti puisi, pepatah, doa, dan sebagainya.

Berdasarkan pendapat ini, ke delapan komponen yang dapat membentuk wujud tuturan, termasuk dalam segi sapaan. Sapaan seseorang kepada mitra tutur tergantung kepada hubungan penutur dengan mitra tutur. Sapaan juga dapat ditentukan oleh situasi formal maupun tidak formal. Tujuan dan bentuk ujar menentukan santun tidaknya sapaan. Cara bicara dan bahasa lisan serta aturan yang berlaku dalam masyarakat tutur juga tidak lepas dari wujud sapaan yang akan diucapkan.

\subsection{Kesantunan Berbahasa}

Kesantunan berbahasa harus diperhatikan oleh setiap pengguna bahasa karena hal ini merupakan subsistem kebudayaan. Ketika melakukannya, seseorang harus mengetahui siapa orang yang disapa, di mana, kapan, dan dalam situasi apa, kemudian memilih kata sapaan yang tepat. D engan demikian. Aspek sosial budaya harus dipertimbangkan dalam menggunakan sapaan, apakah yang disapa lebih tua, sederajat, lebih muda, anak-anak, status sosialnya bagaimana, situasi formal atau tidak, akrab atau tidak, pria atau wanita, dikenal atau tidak, dan lain sebagainya (Chaer, 2010:173).
Kesantunan berbahasa mengacu pada pilihan kata, intonasi kalimat, ungkapan, nada bicara, dan gaya. Hal-hal yang harus dihindarkan agar santun dalam berbahasa, yaitu jangan merendahkan lawan bicara, jangan sombong atau memuji diri sendiri, dan jangan menunjukkan rasa senang atas penderitaan orang lain. A dapun hal yang harus dilakukan, yaitu membuat lawan bicara senang dan menggunakan kosakata yang secara sosial budaya terasa lebih santun dan sopan (Santosa, dkk. 2016:20-21).

Dengan demikian, masalah kesantunan berbahasa harus diperhatikan saat melakukan komunikasi. Kesantunan berbahasa ini antara satu tempat dengan yang lainnya dapat sama atau berbeda. Penutur dan mitra tutur harus memahami hal tersebut. Penting untuk mengetahui budaya santun dalam komunitas bahasa terlebih dahulu agar saat berkomunikasi tidak menyalahi aturan yang berlaku pada masyarakat tutur.

\section{METODOLOGI}

Jenis penelitian ini adalah deskriptif kualitatif. Penelitian ini mengkaji dan mendeskripsikan data apa adanya sesuai dengan yang ditemukan di lapangan. Djajasudarma (2010:14-16) menyatakan bahwa penelitian kualitatif deskriptif menekankan kualitas data (bukan angka-angka) dengan ciri-ciri alami.

Selanjutnya, pendekatan yang digunakan dalam penelitian ini adalah pendekatan sosiopragmatik ebab penelitian yang mengkaji tentang penggunaan sapaan dalam kehidupan sosial pada masyarakat daerah dapat digali berdasarkan sudut pandang linguistik dan konteks tutura

Pengumpulan data dilakukan di D esa Gambah, Kabupaten Hulu Sungai Selatan, Provinsi Kalimantan Selatan. Desa ini dipilih karena merupakan salah satu desa yang jauh dari pusat kota sehingga masyarakatnya masih menggunakan 
bahasa Banjar asli dan belum dipengaruhi oleh bahasa pendatang. Waktu pengumpulan data selama bulan Januari-Juni 2017. D ata yang diperoleh kemudian dianalisis sesuai dengan kajian teori.

Pengumpulan data dilakukan dengan metode simak dengan teknik sadap dan teknik libat langsung. Artinya, peneliti selain melakukan perekaman dengan teknik sadap juga turut melibatkan diri secara pasif atau reseptif dalam tuturan masyarakat setempat dengan teknik libat langsung. Namun, berhubung secara reseptif peneliti hanya mendengarkan dan memperhatikan apa yang terjadi dalam peristiwa masyarakat setempat.

Pengkajian data melalui metode padan. Metode ini alat penentunya adalah di luar bahasa. Peneliti menentukan analisis berdasarkan kajian pragmatik, yaitu partisapan menentukan hasil kajian (lihat Djajasudarma, 2010:66). Penyajian data menggunakan kata-kata biasa. Namun, sebelum itu, melalui langkah kerja, penulis menempuh tiga langkah kerja, yaitu tahap pengumpulan data, pengolahan data, dan tahap penyajian hasil analisis data. Hal ini sesuai dengan yang dimaksudkan Sudaryanto (2015:6-8)

\section{HASIL PENELITIAN}

\subsection{Penggunaan Sapaan A cil "Bibi" dalam Tuturan Bahasa Banjar Berdasarkan Kategori}

Berdasarkan hasil penelitian ini, penggunaan sapaan A cil "bibi" dalam tuturan bahasa Banjar terdiri atas beragam kategori sapaan. Berikut penjelasannya.

\section{Kategori Panggilan Sayang}

Data 1

P: Uh Adil Pupa, lagj baapa?

"Hei Bibi Pupa, sedang apa?"

MT: Ih Mama Caca, ulun lag main masak-masakan

"Eh Ibu Caca, saya sedang bermain masakmasak"
D ata 1 dituturkan oleh partisipentuturan yang terdiri atas penutur dan mitra tutur yang memiliki hubungan dekat. Penutur merupakan seorang tetangga yang usianya lebih tua (P) dibandingkan mitra tutur (MT). Penutur merupakan ibu muda yang berusia 35 tahun, mitra tutur merupakan anak perempuan berusia 10 tahun. Settingtuturan berlangsung saat mitra tutur sedang berada di halaman rumahnya. Penutur menyapa mitra tutur dengan ujaran yang terdengar jelas UhAal Pupa, lag baapa? "Hei Bibi Pupa, sedang apa?" Tuturan ini memiliki makna penutur menanyakan kegiatan apa yang sedang dilakukan mitra tutur.

Penutur menggunakan sapaan Adi "bibi" karena anak-anak di sekitar rumah mereka sering memanggil mitra tutur dengan sebutan Aal "bibi". Anak-anak tersebut menganggap mitra tutur sebagai bibi mereka, karena usia anak-anak lebih muda daripada mitra tutur. Budaya Banjar, apabila usia penutur setara dengan usia anak mitra tutur, kebiasaannya adalah mitra tutur harus disapa Adil "bibi". Penutur yang usianya lebih tua dari mitra tutur, dapat memanggil Adil "Bibi" untuk menunjukkan rasa kasih sayangnya. Ungkapan rasa sayang dalam konteks data 1 ini sama dengan ungkapan 'Nak' atau'Anak' yang sering digunakan oleh masyarakat Banjar pada umumnya untuk menyapa anak-anak di sekitar mereka yang usianya jauh lebih muda. Ada perasaan tidak nyaman atau merasa tidak pada tempatnya apabila langsung memanggil nama saat menyapa orang sekitar yang dikenal.

Dengan demikian, panggilan Aal "bibi" pada data 1 termasuk kategori sapaan saying. Di samping itu, penutur juga memiliki hubungan dekat dengan mitra tutur karena sejak bayi sering diasuh oleh penutur. Penutur sering memangku dan menggendong serta membawa mitra tutur ke mana pun penutur pergi. Hubungan kasih sayang terlihat dalam hubungan mereka tersebut. Nengsih 
(2013:53 - 77) panggilan sayang digunakan saat menyapa lawan bicara yang mempunyai sifat hubungan intim, akrab, dan penuh kasih.

Selain itu, bentuk ujaran yang dituturkan oleh penutur bermodus kalimat pertanyaan atau interogatif yang lembut. Meskipun berbentuk tindak tutur imperatif, tidak terdapat nada keras di dalamnya. Tujuan kalimat yang dituturkan untuk menyapa anak tetangganya tersebut. Senyum sumringah merekah di bibir penutur dengan wajah ceria mengiringi konteks tuturan yang di dalamnya terdapat unsur perasaan suka terhadap mitra tutur. D engan demikian, penutur berupaya memberikan rasa senang dan sayang kepada mitra tutur melalui sapaannya sekaligus memberikan perhatian kepada mitra tutur. Hal ini sesuai dengan pengertian sayang dalam KBBI (2008:1234) sayang adalah berhubungan dengan perasaan suka, mengasihi, dan belas kasihan.

Sementara itu, berdasarkan tujuan tindak tutur, sapaan yang dilakukan oleh penutur kepada mitra tutur sebagaimana contoh data 1 termasuk tindak tutur konvival atau sosial. Penutur melakukan sapaan dalam rangka menjaga hubungan baik dan menjalin keakraban dan mencurahkan rasa sayangnya kepada mitra tutur. Mitra tutur merupakan bagian dari tetangga di sekitarnya. Berarti, mitra tutur bagian dari kehidupan sosialnya. Leec (1993:162) dalam Baryadi (2012:31-32) menyatakan bahwa konvival adalah tindak tutur yang sejalan dengan tujuan sosial.

Sebagai wujud tuturan yang memiliki tujuan sosial yang baik, data 1 menggambarkan bahwa terdapat kesantunan berbahasa di dalamnya. $\mathrm{Pe}$ nutur memperhatikan nilai kesantunan yang berlaku dalam masyarakat Banjar. Aturan tidak tertulis dalam kehidupan masyarakat Banjar, jika bertemu seseorang, baik sengaja atau tidak, sebaiknya saling menyapa. Hal ini sudah dilakukan penutur. Nengsih (2013:46) menyatakan dalam menjaga kelangsungan komunikasi yang baik, mereka saling sapa dengan saling panggil nama merupakan hal yang terjadi sehari-hari.

\section{Kategoni Istilah Kekerabatan}

Data 2

\section{P: Adi Aluh, Paman jar kada bulik siang ngini.} Hidn lag rami maunjun di pahumaan

"Bibi A luh, Paman katanya tidak pulang siang ini, Beliau sedang asik memancing di sawah". MT: Uuh iyakah Han paman ikamtuh kayaitu Bila kaasikan maunjun kada ingat bulik inya.

"O oh begitu. Kan paman kamu itu seperti itu. Bila keasyikan memancing tidak ingat pulang dia".

Data 2 dituturkan oleh seorang keponakan kepada bibinya. Hubungan kedua partisipan tuturan memiliki hubungan darah atau keluarga yang sangat dekat. Keponakannya berusia sekitar 15 tahun, si bibi berusia sekitar 40 tahun. Setting yang ada saat tuturan berlangsung, keponakan mitra tutur sengaja datang ke rumah mitra tutur. Kesengajaan ini dilakukan karena mendapat amanah untuk menyampaikan pesan dari suami mitra tutur kepada mitra tutur. Adil Aluh, Pamanjarkada bulik siangngini. Hidinlagi rami maunjundi pahumaan "Bibi Aluh, Paman katanya tidak pulang siang ini, Beliau sedang asyik memancing di sawah".

Penutur menggunakan sapaan Adil Aluh"Bibi Aluh" kepada mitra tutur. Sapaan ini termasuk sapaan kekerabatan. Penutur merupakan anak dari saudara mitra tutur. Terdapat hubungan keturunan antarpartisipan. Panggilan kekerabatan ini terjadi karena adanya hubungan keturunan dan perkawinan. Nengsih (2013:53- 77) menyatakan bahwa panggilan kekerabatan merupakan suatu bentuk hubungan keturunan dan perkawinan.

Bentuk ujaran lisan yang dituturkan penutur bermodus pernyataan atau deklaratif. Bentuk ujar seperti ini disebut dengan tindak tutur asertif. Penutur menyatakan atau memberitahukan kepada 
mitra tutur bahwa suami mitra tutur tidak pulang ke rumah siang itu karena sedang memancing di sawah. Penutur mengujarkan ujaran 2 dengan intonasi datar, nada lembut, dan diiringi senyum di wajahnya. Penutur pun kembali mengembangkan senyum kala mendengar jawaban bibinya selanjutnya Uuh iyakah. Han paman ikam tuh kayaitu Bila kaasikan maunjun kada ingat bulik inya. "O oh begitu. Kan paman kamu itu seperti itu. Bila keasyikan memancing tidak ingat pulang dia".

Penggunaan bentuk kebahasaan Adi Aluh "Bibi Aluh" yang diujarkan penutur dalam data 2 tentu mempertimbangkan konteks budaya Banjar yang santun. Sapaan tersebut melambangkan nilai. Nilai yang dimaksud merupakan sebuah tanda penghargaan terhadap kerabat yang lebih tua dari penutur. Nilai penghargaan bahwa mereka berdua memiliki hubungan kekerabatan.

Berdasarkan tujuan tindak tutur, sapaan yang terdapat pada data 2 termasuk tindak tutur konvival karena penutur telah menjaga budaya santun berbahasa sesuai dengan budaya sapaan masyarakat Banjar agar tetap terjalin hubungan baik antara partisipan sebagai satu keluarga. Seseorang dikatakan memiliki kesantunan saat menggunakan sapaan jika dia mempertimbangkan konteks budaya kesantunan sebuah komunitas tutur. (Chaer, 2010173) menyatakan bahwa aspek sosial budaya harus dipertimbangkan dalam menggunakan sapaan, apakah yang disapa lebih tua, sederajat, lebih muda, anak-anak, status sosialnya bagaimana, situasi formal atau tidak, akrab atau tidak, pria atau wanita, dikenal atau tidak, dan sebagainya.

\section{Kategori Sapaan Hormat}

Data 3

\section{P: Adil badahulu lah}

"Bibi saya duluan ya"

MT: Ayuha Nak ai, kada pepa

"Iya Nak, tidak apa-apa".
D ata 3 dituturkan oleh partisipantuturan yang terdiri atas penutur (P) dan mitra tutur (MT) yang tidak saling kenal. Penutur adalah warga kampung Gambah. Mitra tutur merupakan tamu tetangga penutur. Penutur berusialebih muda dibandingkan dengan mitra tutur. Settingyang terdapat pada data 3 ini, yaitu saat penutur berjalan di jalan utama desa. Di tengah jalan, dia melihat seseorang yang usianya jauh lebih tua darinya, seumuran bibinya sedang berjalan di depannya. Penutur menyapa mitra tutur dengan ujaran Acil badahulu lah "Bibi saya duluan ya". Tuturan ini memiliki makna bahwa penutur menyatakan dia akan mendahului jalan mitra tutur.

Penutur menggunakan sapaan Adi "Bibi" karena menganggap mitra tutur memiliki usia yang lebih tua darinya. Tidak ada hubungan kekerabatan antara keduanya. Mereka berdua juga tidak saling kenal. Penutur menggunakan sapaan lisan ini sebagai wujud rasa hormatnya kepada mitra tutur. Penutur tidak mungkin menyapa dengan menggunakan langsung kata hii "hei" kepada orang yang ada di depannya tersebut. A pabila dia melakukan hal tersebut maka kemungkinan besar penutur dapat dikatakan orang yang tidak menjunjung norma budaya santun berbahasa yang berlaku.

Penggunaan sapaan Adi "Bibi" untuk orang yang usianya lebih tua meskipun tidak dikenal merupakan cermin budaya santun berbahasa yang dimiliki masyarakat Banjar. Sapaan pada data 3 ini bukanlah sebuah sapaan tanpa nilai. Di dalamnya memiliki nilai berharga, yaitu nilai penghormatan. Hal ini sesuai dengan apa yang katakan tidak terdapat dalam daftar pustaka (1972:2) bahwa Nilai yang dilambangkan dengan penggunaan bentuk-bentuk kebahasaan termasuk pula bentuk sapaan, antara lain sikap dan perasaan hormat terhadap pihak yang disapa. KBBI (2008:507) menyatakan homat adalah perbuatan menghargai, sopan, atau menyatakan perasaan takzim. 
Selanjutnya, sapaan Adil "Bibi" ini menggunakan modus kalimat tutur yang berwujud deklaratif. Penutur memberitahukan kepada mitra tutur bahwa dia akan mendahului mitra tutur. Tujuan tuturan untuk menyapa mitra tutur sekaligus sebagai bentuk rasa hormat penutur. Penutur menunjukkan rasa hormatnya kepada mitra tutur melalui sapaan tersebut. Penutur menunjukkan bahwa dia bukanlah warga masyarakat Banjar yang tidak sopan. Penutur telah melakukan tindal konvival yang memiliki tujuan sosial dan bentuk tindak tutur yang dipergunakan oleh penutur termasuk tindak tutur direktif secara tidak langsung. Penutur secara tidak langsung meminta izin kepada mitra agar dia diperbolehkan mendahului mitra tutur saat berjalan. Mitra tutur pun mengiyakan dengan ramah. Ayuha Nak ai, kada papa "Iya, Nak, tidak apa-apa." Hal ini sesuai dengan apa yang dimaksudkan oleh Rahardi (2009:17) bahwa tindak tutur direktif adalah tidak tutur yang dimaksudkan agar lawan bicara melakukan sesuatu, fungsinya seperti meminta, bertanya, dan lain-lain.

\section{Kategori Julukan}

D ata 4

P: Cil, kaya apa gawian kita?

"Bi, bagaimana pekerjaan kita?"

\section{MT: Tananghaja, sudah kugawi, ikampangkaya apa sudahkah jua tuntung?}

"Tenang saja sudah kukerjakan, kamu sendiri bagaimana, sudah selesai belum?"

D ata 4 dituturkan oleh partisipan tuturan yang sebaya usianya. Settingterjadinya tuturan di sebuah kantor pemerintah di Kandangan, Kabupaten Hulu Sungai Selatan. Saat itu, penutur dan mitra tutur bertemu di lorong gedung kantor tempat mereka berdua bekerja. Penutur dan mitra tutur sama-sama sedang diberi tugas oleh kepala kantor untuk menyelesaikan sebuah tugas.
Cil, kaya apa gavian kita? "Bi, bagaimana pekerjaan kita? Modus tuturan interogatif dengan bentuk tindak tutur direktif ini diujarkan penutur untuk menanyakan apakah tugas mitra tutur sudah selesai. Mitra tutur pun menjawab dengan senyum riang tanpa beban Tananghaja, sudah kugawi, ikam pang kaya apa sudahkah jua tuntung? "Tenang saja sudah kukerjakan, kamu sendiri bagaimana, sudah selesai belum?"

Ketika tuturan ini terjadi, terlihat mitra tutur tidak merasa keberatan kalau panggilan lisan pengganti namanya adalah Adi "Bibi". Padahal, penggunaan kata ini bisa saja menunjukkan bahwa mitra tutur dari segi usia lebih tua dari penutur, meskipun kenyataannya tidak demikian. Sapaan ini termasuk dalam kategori sapaan julukan.

Penutur sebenarnya menyapa dengan sebutan Adi "Bibi kepada mitra tutur sebab mitra tutur selama ini dikenal dengan julukan Aol "Bibi". Panggilan seperti ini tidaklah bersifat resmi. Nengsih (2013:65) menyatakan bahwa julukan adalah nama secara tidak resmi untuk memanggil seseorang berdasarkan nama diri, sifat, pekerjaan, atau ciri khas fisik pemilik nama.

Berdasarkan kenyataannya, selama ini, mitra tutur memiliki perilaku senang mengomel. O melannya kadang menjengkelkan orang sekitar. Namun, mitra tutur tidak merasa dia senang mengomel. Kebiasaan masyarakat Banjar, jika melihat perempuan yang memiliki sifat senang mengomel maka akan diberi julukan Adi "Bibi". Hal ini yang terjadi dalam konteks tuturan data 4.

Tidak ada pelanggaran norma kesantunan berbahasa di sini. Kebiasaan memberikan julukan kepada seseorang menjadi salah satu kondisi yang sering terjadi. Penutur dan mitra tutur saling memahami hal tersebut. Oleh karena itu, penutur menyapa dengan tujuan sosial agar terjalin komunikasi dengan mitra tutur, ternyata mitra tutur menanggapinya dengan santai. Sapaan ini, meskipun menggunakan julukan kepada mitra tutur, tetapi 
mampu menjalin hubungan yang akrab. Chaer (2010:104- 105) sapaan adalah ujaran atau tuturan santun yang kita gunakan untuk menegur mitra tutur saat berjumpa, sengaja atau tidak sengaja di suatu tempat. Ujaran ini bisa berupa kata, frasa, dan kalimat, bahkan narasi. Ujaran biasanya disertai senyum dan anggukan kepala. Tegur sapa antarpenutur dan mitra tutur ini akan menciptakan situasi yang harmonis dan menyenangkan.

\section{Kategori untuk Memanggilkan Anak}

Data 5

\section{P: Cuba ti Nak lihati Adil Ijumbungas banar kalu han ini?}

"Coba lihat Nak Bibi Ijum cantik sekali kan hari ini?"

\section{MT: ikamnih bisa banar, mahimmg kawan}

"Kamu ini pandai sekali, memberi rasa senang terhadap teman"

Data 5 dituturkan oleh seseorang kepada temannya. Usia kedua partisipan tersebut sebaya. Settingterjadi sore hari. Penutur berjalan melewati salah satu rumah di Desa Gambah. Mitra tutur terlihat rapi karena sudah selesai mandi. Mitra tutur terlihat duduk santai di beranda rumahnya. Penutur yang kala itu kebetulan sedang menggendong anaknya yang berusia satu setengah bulan pun melakukan sapaan dengan menggunakan kata Adi "bibi" kepada temannya tadi Cubati Nak lihati Adil Ijumbungas banar kalu hari ini? "Coba lihat, Nak, Bibi Ijum cantik sekali kan hari ini?"

Modus tuturan yang dilakukan oleh penutur adalah kalimat interogatif. Ujaran yang keluar dari ungkapan perasaannya tersebut dilakukan sebagai sebuah cara mengajarkan si anak agar melakukan sapaan kepada mereka yang ditemui, baik sengaja atau tidak sengaja. Panggilan kata Adi "bibi" itu pun sebagai bahan ajar bagi si anak agar memanggil orang yang usianya sebaya dengan ibunya dengan sebutan Adi "bibi". Harapan penutur, kelak apa yang dilakukannya tersebut akan dilakukan pula oleh si anak yang masih berusia di bawah lima tahun tersebut.

Berdasarkan latar belakang penggunaan kata sapaan Adil "Bibi" oleh penutur ini, meskipun penutur seusia dengan mitra tutur, tetapi dia akan tetap menggunakan sapaan "memanggilkan" kepada temannya untuk si anak. D engan demikian, data 5 tidak termasuk dalam kategori sapaan sebagaimana yang dikemukakan Biber dalam Isa (2010:46) yang menekankan bahwa sapaan penting untuk menjelaskan dan memelihara hubungan sosial antara partisipan di dalam percakapan. Mereka membagi sapaan menjadi delapan kategori berdasarkan penggunaannya, yaitu (1) panggilan sayang; (2) istilah kekerabatan; (3) panggilan akrab; (4) nama akrab; (5) nama depan utuh, (6) gelar dan nama belakang; (7) sapaan hormat; dan (8) sapaan lain yang termasuk julukan.

Bentuk imperatif terlihat dalam sapaan lisan penutur. Penutur seakan-akan meminta jawaban dari si anak akan ujaran yang dia ajukan. Namun, di balik tindak tutur imperatif tidak langsung tersebut, terdapat nilai pembelajaran di dalamnya. Data 5 ini hanya salah satu data dari beberapa data yang memiliki maksud tuturan yang sama dalam komunikasi antara warga pada masyarakat Banjar.

Tujuan umum dari sapaan penutur memang bersifat konvival atau sosial demi menjalin hubungan baik antarwarga masyarakat setempat. Tujuan tuturan ini juga memiliki maksud yang mengandung kesantunan berbahasa. Masyarakat Banjar memiliki budaya "Memanggilkan" bagi anak kecil ketika menyapa seseorang. Budaya ini menjadi bagian keseharian bagi mereka. Bagian dari kategori sapaan yang memperhatikan kaidah sosial budaya yang berlaku. Hal ini sesuai dengan apa yang dinyatakan (Chaer, 2010:173) bahwa aspek sosial budaya harus dipertimbangkan dalam menggunakan sapaan, apakah yang disapa lebih 
tua, sederajat, lebih muda, anak-anak, status sosialnya bagaimana, situasi formal atau tidak, akrab atau tidak, pria atau wanita, dikenal atau tidak, dan lain sebagainya.

\section{PENUTUP}

\section{Simpulan}

Berdasarkan hasil penelitian dapat disimpulkan bahwa penggunaan kata sapaan Adil "Bibi" dalam masyarakat Banjar terdiri atas kategori panggilan sayang, hubungan kekerabatan, sapaan hormat, panggilan julukan, dan kategori "memanggilkan diri di luar penutur". Kelima kategori ini dapat diketahui melalui peristiwa tutur yang melatarbelakanginya. Sapaan ini memiliki bentuk, modus tuturan, dan tujuan tuturan. Kelima sapaan Aail "Bibi" dalam penelitian ini memiliki tujuan tutur yang sama, yaitu bertujuan sosial atau kovival.

\section{Saran}

Hasil penelitian ini dapat dijadikan salah satu referensi bagi peneliti lain yang akan mengkaji masalah sapaan dalam bahasa Banjar. Peneliti berharap agar dilakukan pengkajian lebih dalam tentang sapaan bahasa Banjar dalam jenis yang berbeda dan teori yang berbeda. Semoga hasil penelitian ini dapat bermanfaat bagi dunia Pendidikan dan dapat dijadikan sebagai salah satu materi dalam muatan lokal di sekolah-sekolah.

\section{DAFTAR PUSTAKA}

Aslinda , dkk. 2010. Pengantar Sosidinguistik. Bandung: PT. Refika Aditama.

Baryadi. I.Praptomo. 2012. Bahasa, Kkkuasaan, dan

Kekerasan Yogyakarta: Universitas Sanata D harma

Chaer, Abdul dan Agustina. 2010. Sosidinguistik:

Perkenalan Awal. Jakarta: Rineka Cipta
Chaer, A bdul. (2012). Sosidinguistik. Jakarta: Rineka

Djajasudarma, T. Fatimah. 2010. MetodeLingistik. Bandung: Refika Aditama

Fisman, J.A. 1972. Reeding In the Sosidogy Of LanguageParis: The Haque-Mounton Publisher

Isa, Ari Andrasyah.2010. "Tutur Sapa.” Jumal vidyaparna 38 (1) : 45-57.Yogyakarta:Balai Bahasa Yogyakarta.

Jahdiah. 2003. Kata Sapaan Bahasa Banjar Kuala Banjarbaru: Balai Bahasa Banjarmasin Nengsih, Sri Wahyu. (2013). Variasi Panggilan dalam Tuturan Sapa Masyarakat Banjar. dalam Bunga Rampai Bahasa (hlm. 46-79). Banjarbaru: Balai Bahasa Provinsi Kalimantan Selatan

Rahardi R. Kunjana.( 2009). Sosiopragmatik. Jakarta:E rlangga.

Rohmadi. (2011). Analisis Wacana Pragmatik. Surakarta : Yumna Pustaka

Santosa, Puji dan Jaruki Muhammad.2016. Mahir Berbahasa Indonesia, Baik, Benar, dan Santun. Bamdung Rosda

Sudaryanto.( 2015). MetodedanAnka Tkznik Ana lisis Bahasa Jakarta: D uta Wacana University Press.

Tim. 2008. KBBI edisi keempat. Jakarta: PT Gramedia Pustaka Utama.

Sumarsono. (2007). Sosidinguistik. Yogyakarta: Sabda

Tarigan, Henry G untur. 2009. PengajaranPragnatik. Bandung: Angkasa

Wijana, I D ewa Putu dan Muhammad Rohmadi. 2004. Sosiolinguistik: Kajian Teori dan Analisis. Cetakan: pertama. Yogyakarta: Pustaka Pelajar.

Wijana, I D ewa Putu dan Muhammad Rohmadi. 2011. Analisis Wacana Pragnatik. Surakarta : Yumna Pustaka 
Kadera Bahasa, Volume 9, Nomor 1, Edisi April 2017

Geza, Aulia Akmal. 2016. Variasi Kata Sapaan Kekeabatan Bahasa Mdayu Jambi d Desa Bukit

Telago Tesis. Program Pascasarjana

Universitas Andalas. Padang 